Biro, Ruth G. "Review Article: The Vanished Ghosts in Two Hungarian Family Memoirs. Farkas, Charles. 2013. Vanished by the Danube and Barlay, Nick. 2013. Scattered Ghosts." Hungarian Cultural Studies. e-Journal of the American Hungarian Educators Association, Volume 7 (2014): http://ahea.pitt.edu DOI: 10.5195/ahea.2014.142

\title{
Review Article: The Vanished Ghosts in Two Hungarian Family Memoirs. Farkas, Charles. 2013. Vanished by the Danube: Peace, War, Revolution, and Flight to the West (Introduction by Margaret McMullan). Albany: Excelsior Editions, State University of New York Press. 472 pp. Illus; and Barlay, Nick. 2013. Scattered Ghosts: One Family's Survival through War, Holocaust and Revolution. London and New York: I. B. Tauris. 240 pp. Illus.
}

\section{Ruth G. Biro}

\begin{abstract}
Recent personal documentary works about major historical events of the twentieth century, e.g., World War II, the Holocaust and the 1956 Hungarian Revolution, offer their readers a rich and multifaceted narrative, or a history that is also "his story," "her story" and that of entire families, cohorts and communities. Often, these works are accompanied by visual artifacts such as photographs, family tress, maps etc., or supported by concise historical surveys. Thus these memoirs complete the work of historians with the lived experiences of the few that represent many. Such is the case with two 2013 books by Charles Farkas and Nick Barlay depicting their mid-twentieth century Hungarian families, one Christian and one Jewish, through two World Wars and the anti-communist uprising, culminating in their escape to the West and in the two authors looking back upon the Hungarian past of their families.
\end{abstract}

Keywords: Memoir, war and life writing, Hungarian Jews, World War II, Holocaust, 1956 Hungarian Revolution

Biography: Ruth G. Biro co-authored the Hungarian-English Picture Dictionary for Young Americans with Miklós Kontra and Zsófia Radnai (Budapest: Tankönyvkiadó, 1989). She researches children and young adult literature, Righteous Gentiles, Raoul Wallenberg, Hungarian Holocaust literature by women in the USA, and other Hungarian and Hungarian-American topics. Her article on "Representations of Budapest in 1944-1945 in Holocaust Literature" was published in Comparative Central European Holocaust Studies (eds. Louis O. Vasvári and Steven Tötösy de Zepenek; West Lafayette, IN: Purdue University Press, 2009, 3-17). Ruth G. Biro is the 2012 recipient of the Peter Basa Award of the American Hungarian Educators Association. 
Biro, Ruth G. "Review Article: The Vanished Ghosts in Two Hungarian Family Memoirs. Farkas, Charles. 2013. Vanished by the Danube and Barlay, Nick. 2013. Scattered Ghosts." Hungarian Cultural Studies. e-Journal of the American Hungarian Educators Association, Volume 7 (2014): http://ahea.pitt.edu DOI: 10.5195/ahea.2014.142

The two books under discussion -- one by the Hungarian-American Charles (Károly) Farkas and the other by Nick Barlay, second-generation to Hungarian-Jewish refugees presently living in England -- recall four generations of their family histories. Both volumes, Vanished by the Danube: Peace, War, Revolution, and Flight to the West by Farkas and Scattered Ghosts: One Family 's Survival through War, Holocaust and Revolution by Barlay, cover the early nineteenth-century and onward with special focus on World War I, the interwar period, World War II and the Holocaust, the 1956 Hungarian Revolution and beyond. Charles Farkas, born November 26, 1925 in Budapest, reports on his first-hand experiences with his close-knit relatives as well as about events he observed in Hungary in his childhood, teenage, and early adult years, all reconstructed over fifty years after he immigrated to the United States in January 1957. His chronological account in this lengthy tome Vanished by the Danube is detailed, selfassured, and precise, lucidly revealing his own and his family history in many locales in and around Budapest. The author's superb recollections from personal memory are accompanied by many photographs and other visual materials. In contrast, author Nick Barlay was born in 1963 in England to emigré parents István and Ági Bokor (later Barlay), who left Hungary on December 9, 1956 for Austria and arrived almost by accident in Dover, England on December 23 of that year. Nick Barlay, named one of Granta Magazine's best young British novelists in 2003, found himself pursuing a writing career like his journalist/writer father Stephen Barlay. Nick Barlay relied upon anecdotes of relatives, genealogical research, archival documents, and incomplete, unverified, or imaginary fragments to piece together the captivating story of his farflung relatives over a period of two hundred years until today. Scattered Ghosts, researched by Barlay under an award from the Arts Council of England, is composed of inventive vignettes and reads like a novel despite its scholarly references and reliance on in-depth research conducted in archives in Hungary, Romania, Slovenia, Slovakia, Austria, the Auschwitz-Birkenau Memorial and Museum, the British Library, and Wiener Library. This book was also recently published in Hungarian as Szellemek nyomában - családregény (Nick Barlay 2014).

In the Farkas book it is abundantly clear that the author knew well the relatives and the historical events he describes, as oftentimes his text is accompanied by old family photographs that by now constitute the only material testimony to his past, vanished world. By contrast, in Barlay's book the family "ghosts" -- meaning souls, people who once were -- he never knew and many he never even knew to have ever existed reveal themselves in vivid vignettes that the author composed based on his diligent research. For Farkas the stories were always there as real, retold and reinforced. Barlay, however, had to first discover facts and documents, then imagine the narratives to be told once the persons and events came to life, and finally unravel or intertwine the emerging threads into stories. Both authors describe worlds that have by now disappeared: Farkas recalls the lost world of the past while Barlay writes about a lost world he rediscovered. Cultural identity for Farkas is embedded in the comfortable and unquestioned history of his Christian family, whereas for Barlay his newly found ghost-relatives from various Diasporas are distinctly Jewish in their beliefs and fate. Coincidently, the fathers of both authors worked at the Budapest Hungarian Radio Station at different time periods. Charles's father was editor of Rádió Élet when Charles was born. Barlay's father was a freelance writer at the Hungarian Radio until he left Hungary in 1956. The mothers of both authors were writers and worked in creative arts: painter Rózsi Farkas as a journalist for Újság and Esti Újság, and Ági Bokor as a writer and photographer. Both Farkas (born 1925) and Barlay's father (born 1930) read the same works by German writer Karl May about the American West, which May had 
Biro, Ruth G. "Review Article: The Vanished Ghosts in Two Hungarian Family Memoirs. Farkas, Charles. 2013. Vanished by the Danube and Barlay, Nick. 2013. Scattered Ghosts." Hungarian Cultural Studies. e-Journal of the American Hungarian Educators Association, Volume 7 (2014): http://ahea.pitt.edu DOI: 10.5195/ahea.2014.142

never even visited. Still, May's works were very popular with European and Hungarian youth of the early twentieth century. Both Farkas and Barlay describe the city of Budapest during two World Wars, two oppressive regimes, and the 1956 Hungarian Revolution, thus offering two very different narratives and vantage points of the same historical events.

In his detailed memoir of his life in Hungary during the period from 1925 to 1956, Charles Farkas reminisces about his extended family as well as the landmarks and milestones that shaped his own life in Hungary starting in the interwar period, going through World War II and the 1956 Hungarian Revolution, and ending with his arrival to the U.S. in January 1957 aboard the U.S.N.S Marine Carp. Farkas began his university studies at Pázmány Péter University in 1943 and earned a double doctorate, in law and political science, in 1949. After settling in the U.S. as a refugee, Farkas earned a master's degree in library science from Columbia University and held the position of director of the Briarcliff Manor Public Library from 1968 until 1996. With his Hungarian-born wife Edit, who had experienced forced relocation to the East in the 1950s communism, they raised four children in the U.S. and at present reside in Chappaqua, New York. Aiming to present his real life as experienced in the flesh, Farkas tells his eye-witness story of the middle and upper classes in the genteel years before the turbulence of the Nazi occupation in 1944, the horrors of the siege of Budapest, and the tribulations of the later communist era. In his prologue, Farkas expresses his sorrow that the culture, social values, traditions, integrity, and morality that once were in the grand city of Budapest spanning the river all changed with World War II, which is why personal accounts such as his Vanished by the Danube serve to recapture a time, place, and way of life that have all disappeared.

The penetrating introduction to the Farkas volume by Margaret Mullan, an Evansville University literary scholar, stresses the importance of memory relating to historical settings of long ago as preserved by those who experienced the joys and traumas of the bygone period. Mullan's succinct summary clarifies that Farkas's story of his thirty years in Hungary is further enhanced by his reflections as a Hungarian American. Within the fifty-one chapters of the book, Farkas acquaints his readers with the cafe life of his parents and the famous writers, scholars, and artists who interacted with his family over the years. His father Jenö, a professional writer and editor of the Hungarian Radio's magazine Rádió Élet, was discharged from the Hungarian Broadcasting Corporation on Januáry 1, 1947. His mother Rózsi, a journal columnist and painter, became a member of the Budapest co-operative of graphic artists during the communist period. In Chapter One we learn that their family lineage included great-grandfather Károly Farkas, who served in the Ministry of Finance in the revolutionary cabinet of Louis Kossuth in 1848.

Charles's childhood, school programs, notable teachers, scout activities, teenage friendships and many members of his colorful family are described in Chapters Two to Nineteen, and even his favorite foods are presented with carefully crafted descriptions. Especially interesting are his discussions of American music, films, books and pictures as they show his -- somewhat naïve -adoration for American culture and its symbols since his early life. Young Charles and his friends enjoyed listening to records by Cole Porter, Glenn Miller, Benny Goodman, Artie Shaw and George Gershwin. They also collected pictures of Clark Gable, Errol Flynn, Spencer Tracy, Jeannette MacDonald, and Nelson Eddy. Charles voraciously read through Karl May's books on American Indians and the Wild West and enjoyed movies such as Dodge City. Accordingly, the photographs in the book show him in his scout uniform, dressed and singing as a cowboy, and playing records with his friends. He even decorated a room in his grandmother's Orszentmiklos home as a sheriff's office. 
Biro, Ruth G. "Review Article: The Vanished Ghosts in Two Hungarian Family Memoirs. Farkas, Charles. 2013. Vanished by the Danube and Barlay, Nick. 2013. Scattered Ghosts." Hungarian Cultural Studies. e-Journal of the American Hungarian Educators Association, Volume 7 (2014): http://ahea.pitt.edu DOI: 10.5195/ahea.2014.142

Hitler's occupation of Hungary, World War II, and the siege of Budapest are covered in Chapters Twenty to Twenty-Six. Here Farkas relates the story of his life-long friend Gyuri Sághy, who befriended Polish military personnel and political or Jewish refugees coming to Hungary following the Nazi invasion of Poland in 1939. Many refugees who did not continue eastward to join the army of Polish General Władysław Anders remained in Hungary and found jobs, attended school, or were sheltered by locals. During the Holocaust of Hungarian Jews, the Christian Farkas family hid a Jewish man in the apiary of the family estate in Veresegyház, just north-east of Budapest. Also in those hard times, their close family friend Artúr Elek, writer and art critic for the literary journal Nyugat, who was a Jewish convert to Catholicism, committed suicide. Farkas later learned that his favorite high school teacher Kalman Miklossy, headmaster at Verboczy, was shot to death at his home in January 1945 by a detachment from the Arrow Cross, because his wife was Jewish. Miklossy, a decorated veteran of World War I, had been previously denounced by two teachers at the high school for his interreligious marriage. The renowned teacher Gyula Grexa, a distant relative of the Farkas family, who became the subject of a biography published by Tankönyvkiadó in 1986, was active in the resistance movement and typed flyers day and night; one such resistance leaflet that was placed in the Farkas's mailbox is presented as a document in Vanished by the Danube.

Other Jewish friends, classmates, or business associates, too, were given refuge or protected by members of Farkas's family; for example, Charles's Aunt Blanka sheltered three of her former Jewish classmates in Budapest. At work, Jenö Farkas called in two dozen Jewish employees at the Radio Broadcasting Corporation and vowed to keep them on the payroll. Also described by Farkas are the Allied bombing raids of Budapest beginning on April 2, 1944, the mass deportations of Jews to Auschwitz from the countryside in May, the Arrow Cross power grab of October $15^{\text {th }}$, the bombing of the Margaret Bridge on November 4, and the terrible siege of Budapest from December 1944 to February 1945. Once they broke into Hungary, the Russian soldiers raped, pillaged, looted at will and were preoccupied with stealing wristwatches, consuming alcohol and wolfing down treasured Hungarian cuisine specialties. This was also when beautifully-bound books from the library of Charles's uncle Rory and Aunt Hansi were destroyed by the Russians, with the torn pages destined to serve as their cigarette paper.

Chapters Twenty-Seven to Forty-Eight describe the post-war era, the Soviet occupation, and the communist take-over of the country. When the siege finally ended in February 1944, the Russians remained. Charles reports on the Russians randomly taking Hungarians off the streets to be sent to Russian work camps. His family's life events are intertwined with political occurrences. Charles earned his doctorate in 1949 and began his new job at the national fruit production company; his father died in April 1951. Stalin's death in March 1953 inaugurated political changes: Imre Nagy's government took over, instituted liberal reforms, and decreased terrorism. Later Nagy was forced to step down and was put under house arrest. Around that time Farkas joined a friend in a bicycle-rickshaw business that carried goods and produce around Budapest, thereby improving his income. It was at that time of the mid and late 1950s that political criticism began to appear in newspapers.

Chapter Forty-Nine concentrates on the Hungarian Revolution of 1956. On October 23 Farkas had lunch in Pest and later he had coffee in the Buda Castle district with his mother and a friend. Demonstrators in a long procession were visible from both locations, and Farkas learned that a crowd was attempting to remove the statue of Stalin, which was soon brought crashing down by winches, welding torches, and steel ropes. People thronged to the Hungarian National 
Biro, Ruth G. "Review Article: The Vanished Ghosts in Two Hungarian Family Memoirs. Farkas, Charles. 2013. Vanished by the Danube and Barlay, Nick. 2013. Scattered Ghosts." Hungarian Cultural Studies. e-Journal of the American Hungarian Educators Association, Volume 7 (2014): http://ahea.pitt.edu DOI: 10.5195/ahea.2014.142

Radio building where they clashed with the AVH, the Hungarian Secret Police. Later, a massacre occurred at the Parliament and Russian tanks crossed the city. On November 4 the new government of Imre Nagy appealed to the United Nations and the free world for assistance, which never came, and a week later the Soviet tanks have gained the upper hand. At one point in the action Charles and others were trapped at the Hungarian Radio building and sought safety in what turned out to be his father's former office.

Chapter Fifty describes Charles's escape to the West after he made up his mind to leave Hungary knowing that his activities would make it difficult to stay in his homeland. After sipping a brandy with his mother, he called his friend Lajos (Lali) László and stuffed a picture of Veresegyház in his pocket. On November $15^{\text {th }}$, Charles and Lali caught a ride in a truck to Tatabaánya and then another to Györ. Awake before daybreak on the $16^{\text {th }}$, they took a third truck to the border near Mosontarcsa/Andau. Charles and Lali crossed the bridge and were in Austria by noon. After some time in several camps set up for Hungarian and other refugees, they set out for Vienna to visit a cousin of Charles's mother, János Lauringer, who worked at the Free Europe Radio Station. While in Vienna, Charles met his childhood friend Gyuri Sághy, celebrated his thirty-first birthday and attended Christmas Eve midnight mass at St. Stephen's Cathedral. Awaiting receipt of a "Grey Card" for transportation and a weekly sum at the Viennese police station, Charles unexpectedly encountered his former girlfriend Judit (Ditta) Hajós, who was scheduled to fly to New Zealand. Shortly thereafter Charles and Lali took a train from Austria to Germany, where at Bremerhaven on January 1, 1957 they would board the U.S.N.S. Marine Carp to the U.S.

Chapter Fifty-One is devoted to Charles's journey to the U.S. The military orchestra that played as the ship pulled anchor was comprised of black musicians who rendered the Hungarian anthem in a bluesy fashion. On board, Charles practiced his English with the foreign learners' book English through Pictures. After a two-week voyage in both calm and stormy seas, 1,725 Hungarian refugees landed in the Brooklyn navy yard. On January 16, 1957, Charles, Lali, Charles's future brother-in-law András Németh and others were sent to (transit) Camp Kilmer in New Jersey. From that location they would be launched into a new beginning in the U.S. The book's short epilogue offers a glimpse of Charles Farkas's first days in the new world and ends with the promise that the "rest is yet to come."

Because Farkas is basically remembering and reconstructing his personal life experiences in Vanished by the Danube, the scholarly works covering the period under discussion are necessarily sparse and restricted to Istvan Deak's Essays on Hitler's Europe (Deak 2003), Lucy S. Davidowitz's The War against the Jews, 1933-1945 (Davidowitz 1975), Krisztián Ungváry's Budapest Ostroma (Ungváry 2001), Tony Judt's Postwar: A History of Europe since 1945 (Judt 2005) and Anne Applebaum's Iron Curtain (Applebaum 2012). Farkas notes that his father kept a diary from the Christmas Eve of 1944 to the Christmas Eve of 1945, which he entitled The Siege and the Besieged (this diary, which is later referred to as a "novel," was never published), and Farkas freely used accounts from it in describing the siege on Budapest, the end of Nazism, and the Russian occupation during that year. An astounding array of photographs graces the Farkas volume and provides remarkable images of his family members and friends. Readers not familiar with the geography of Hungary might have appreciated the inclusion of a map showing villages and towns mentioned in this memoir (Veresegyház, Gödöllö, Vác, Tatabaánya, Györ and other places), as well as a diagram of Budapest locales like the Swiss Embassy, the Glass House, 
Biro, Ruth G. "Review Article: The Vanished Ghosts in Two Hungarian Family Memoirs. Farkas, Charles. 2013. Vanished by the Danube and Barlay, Nick. 2013. Scattered Ghosts." Hungarian Cultural Studies. e-Journal of the American Hungarian Educators Association, Volume 7 (2014): http://ahea.pitt.edu DOI: 10.5195/ahea.2014.142

Gellért Hotel, the Logodi Street residence, György Dózsa Avenue, the Royal Castle, and the Hungarian National Radio Building.

By way of comparison with Farkas's monumental memoir and photo gallery, author Nick Barlay in Scattered Ghosts: One Family's Survival through War, Holocaust, and Revolution presents the story of his family dating back to 1811 and reaching the present, including a family tree he reconstructed and vignettes he composed on his ancestors from many parts of the old Austro-Hungarian Monarchy. Barlay's book is divided into five major sections expressing a conceptual framework rather than a chronological narrative: "Ghosts," "Men," "Women," "1956," and "Parallel Lives." In the book's first chapter or segment, "The Knock," Barlay (reverberating Jewish hasidic narratives of mystical meetings with long deceased people or with supernatural entities) reveals his "dream" of a crowd of relatives -- all dressed in the appropriate clothing of the day -- arriving at his door. After squinting a bit, he begins to "recognize" some of them as those he actually met, some as those he saw only in photographs, and others that he discovered in his research. Dozens of relatives from a period of over two hundred years -arranged in alphabetical order from Berger to Zemler -- come to his door. Barlay begins to match names to faces and starts to realize that many of them experienced World War I, World War II, the Nazi occupation, forced labor service in the Hungarian army, deportations to death and concentration camps, the siege of Budapest, the communist regime, and the 1956 Revolution. Quite a few of these relatives perished in Auschwitz or dodged bombs and bullets in the Hungarian capital, while others were saved by protective passes from foreign embassies. His imagined hosting table is laid with warm dessert, a sour 'meggyes pite' ["cherry pie"], or 'rétes' ["strudel"], perhaps requested by one of his relatives, or made by another following a wellknown recipe passed down through generations, and served especially for this gathering. As Barlay later reveals, the story of his Hungarian Jewish family runs parallel to the story, or rather the incantation, of generations of grandmothers calling upon their offspring: 'Gyere...szedjük a meggyet...' ("Come, let's pick the cherries..."), as recounted in many a Hungarian folk song.

In the book's second chapter, called "Night," Barlay describes a 2006 evening at the Buda Castle District, with his father and brother Robin looking down below at the Danube and at the Parliament in Pest, on the river's opposite side. It has been fifty years since Nick's parents left Hungary and over sixty year since the end of World War II. Yet, it is there, on top of Castle Hill, that he would envision the far-away places from where his relatives came to Budapest long before: Novi Sad in the south, Vienna in the west, Arad at south-east, and The Ukraine at northeast (this is yet another Jewish visionary trope alluding this time to Jacob/Israel's dream of God's promise of the Land of Israel to his children, in Genesis 28, 14). In Barlay's book, his long-gone family members or "ghosts" would point to Pest across the river as an act of remembrance of this family's experiences, which include childhood adventures, poems and addresses, as well as the city's ghetto, Soviet tank shells, bombing and other fearful events. In the third chapter, entitled "The Road," Barlay is reminded of his father's oak desk in England, where his father contemplated the 1456 Siege of Nándorfehérvár and the 1526 Battle of Mohács as well as created a dozen books on modern events and politics, including on his personal experiences.

In the second section of the book, "Men," Barlay tells the stories of three of his male ancestors. In the chapter titled "The Disappearance of a Father," Barlay relates the fate of his fraternal grandfather Nándor Bokor, who disappeared from a Hungarian army Jewish Labor Service (munkaszolgálat) Battalion in 1943, as well as delineates the fates of other relatives who were in the Labor Service, like his maternal grandfather Ernö Semler who survived, and his 
Biro, Ruth G. "Review Article: The Vanished Ghosts in Two Hungarian Family Memoirs. Farkas, Charles. 2013. Vanished by the Danube and Barlay, Nick. 2013. Scattered Ghosts." Hungarian Cultural Studies. e-Journal of the American Hungarian Educators Association, Volume 7 (2014): http://ahea.pitt.edu DOI: 10.5195/ahea.2014.142

grandmother Lili's younger brother Andor, or of his cousin Tomi's father Imre Fenyvesi, who have all perished in the Service. In the chapter about "The Coming of Uncle Józsi," Barlay features his great uncle Józsi Müller (1887-1960), an Austro-Hungarian army captain who served on the Isonzo Front in World War I. Uncle Józsi witnessed the rise of anti-Semitism in the 1920's and later lost his daughter, her husband, and his grandchild in Auschwitz in 1944. It was Uncle Józsi who encouraged young Barlay to read Karl May's book Winnetou, the story of an Apache chief in the American West who promoted understanding of others. In a chapter titled "An Anatomy of a Massacre," Barlay' s father and his cousin Tomi Fenyvesi, hidden in a crate in the cellar, ear-witness the Holocaust massacres of October 1944 on Népszinház Street in the eighth district of Budapest. To Nick, his father's childhood friends resemble boys fighting for their playground territory that he later read about in Ferenc Molnár's Paul Street Boys. István Bokor's classmates included Imre Kertész, The Hungarian-Jewish 2002 Nobel Prize winning author, who then lived one floor below the apartment of Barlay's mother Ági and her sister Zsuzsi (of the Semler family) on Baross Street. Kertész, who was deported to Auschwitz at age fifteen, remained a lifelong friend of Nick's father, with the two maintaining phone contact for seven decades. This portion of Barlay's book also notes the efforts of Raoul Wallenberg, the Vatican, the Swiss legation, and others in rescuing Jews caught in the Hungarian Holocaust.

In the third section of the book "Women," the readers are introduced to three women in Barlay's family. The first of them is Nick's great-grandmother Maria, née Hirschhorn, born 1869, who was deported from Székesfehérvár to Auschwitz in 1944. Barlay visits the city, meanders in the streets, stops at the Jewish cemetery, and examines the Fehér County Archives Records to learn more about the life and times of Maria, her parents, siblings, and her son. At AuschwitzBirkenau, Barlay reads records, scrutinizes heaps of photographs, studies the railroad tracks, and views the crematorium, all in an effort to follow Maria's footprints up to her presumed death on June 17, 1994. The next chapter on women tells the story of Barlay's maternal grandmother Bözsi Karczag (1905-1988), born in Arad, a pianist who studied at the Ferenc Liszt Academy in Budapest. Bözsi survived the death march from the brickyard of Óbuda toward the Austrian border by falling back from the column to tie her shoelaces. Once separated from the rest of the group, she tore off her yellow star and made her way back home. Four decades later, and still resilient in her eighties, Bözsi was still working as a filing clerk in a clinic in Budapest. The last woman described in the section on women is Barlay's own mother Ági. She and her sister Zsusi both married their cousins and best friends -- Ági married István Bokar and Zsusi married Tomi Fenyvesi. Barlay provides a chronology and categorization of key dates relating to his mother's life between the years 1946 and 1956, ending on September 9, 1956, the date of his parent's marriage and shortly before the 1956 Revolution that would result in their immigration to England.

The fourth section of the book covers the 1956 Hungarian Revolution. Three chapters describe the family members who remained in Hungary, the unexpected transport of Barlay's parents from Vienna to England, and the change of identity of the emigrés in the new land. On the evening of October 23 Barlay's father, a freelance writer at the Hungarian Radio, was trapped in the building with other journalists. Barlay writes about the tear gas used by the secret police, the "Sixteen Points" or demands made by the uprising students, the literary Petoffi Circle of the revolutionaries, and the occupation of the Radio building by Soviet forces. On December 6 István and Ági left by bus from Budapest's Deák Square to Györ with forged papers stating that István was on official Radio business. They booked and pre-paid a hotel room en-route as a foil. 
Biro, Ruth G. "Review Article: The Vanished Ghosts in Two Hungarian Family Memoirs. Farkas, Charles. 2013. Vanished by the Danube and Barlay, Nick. 2013. Scattered Ghosts." Hungarian Cultural Studies. e-Journal of the American Hungarian Educators Association, Volume 7 (2014): http://ahea.pitt.edu DOI: 10.5195/ahea.2014.142

István had only his briefcase and Ági clutched a book on Greek mythology, but they carried no luggage to avoid suspicion. They continued westward to Sopron, where the next morning they were hidden in an ambulance and driven to a house in Kopháza. Later, undercover of the moonless night, Ági and István as well as other Hungarian escapees and their guide trudged over bumpy and muddy fields to a clump of bushes that signified Austria. On December 9 they were served cocoa at the Austrian border village reception center. The next day, rather than staying in the refugee camp, they arrived in Vienna and checked into a hotel. Ági and István made the rounds of embassies and received a variety of papers. Ten days later they unexpectedly learned that three buses from England loaded with clothes for the refugees in Austria would shortly be returning back to Britain with refugees. They waited in line, but István could not locate his identity papers. Incredibly, even without proper papers, they were allowed to board one of the refugee buses immediately. On December $23^{\text {rd }}$, Ági and István arrived in Dover, where each bus headed in a different direction. Their bus was sent to a refugee camp north of Wellingore and two days later they were invited for Christmas dinner at the home of a local British family. On February 1957 they moved to London, where István (now Stephen) began to write. In 1959 István/Stephen's mother Lili traded her Budapest flat on Baross Street for a passport to England, and she even carried a marrow-slicer with her to the new country, where she soon felt so at home that she donned a colorful flowery blouse instead of the usual dull grey suit she had worn in her Hungarian life.

In the section entitled "Parallel Lives," Barley focuses on his father's study with its cigarette smoke, eternal espresso cup, clacking typewriter, and myriads of papers -- messages, reminders, pencil corrections, and such. Lili's room was decorated in an old Austria-Hungarian style, which she recreated from pillows she sewed by hand and well-chosen rugs, wardrobes, and other items she bought in English marketplaces. Another chapter tells the story of István's cousin Tomi Fenyvesi and his debilitating accident while walking his dog. Tomi, a psychiatrist, forever regretted not leaving Hungary in 1956. Just another vignette describes Nick's chance meeting in England with a former fascist, who later asks Nick to lend him some money (that he never returned) in order to return to Hungary. The closing chapter, "A Disappearing World," emphasizes the importance of live memories in family histories. It is apparent that Barlay is ready to answer the next knock at the door, keep in touch with the stories of still more of his ancestors, and share a delicious cherry dessert with those yet to visit.

Barlay's bibliography of some sixty entries includes references in English (37), Hungarian (19), titles available in both English and Hungarian (4), and French (1). These items range from two books written by Barlay's father: Stephen Barlay, with Peter Sasdy, Four Black Cars (Stephen Barlay \& Sasdy 1957); and Stephen Barlay, Menekülés és Megérkezés [Escape and Arrival] (Stephen Barlay 2006), to literary works by Imre Kertész, Arthur Koestler, George Konrád, Sándor Márai, Miklós Radnóti, Ernő Szép, Antál Szerb, and Béla Zsolt. Some of the scholars on this list are: Randolph Braham with three books on the Hungarian Holocaust, István Deák (on Jewish soldiers in the Austro-Hungarian era), Géza Komoroczy and others (on Jewish Budapest), John Lukács (on Budapest culture around 1900), Victor Sebestyén (on the 1956 revolution), Kristian Ungváry (on the siege of Budapest), and more. The selected website listing identifies resources regarding the Holocaust in Hungary, Jewish cemeteries and genealogical records, Hungarian Jewish historical/cultural organizations, archives, book collections, and other relevant information sources. At the beginning of his book, Nick Barlay presents a family tree of four generations, which later proves invaluable in sorting out the "ghosts" in his lineage. An 
Biro, Ruth G. "Review Article: The Vanished Ghosts in Two Hungarian Family Memoirs. Farkas, Charles. 2013. Vanished by the Danube and Barlay, Nick. 2013. Scattered Ghosts." Hungarian Cultural Studies. e-Journal of the American Hungarian Educators Association, Volume 7 (2014): http://ahea.pitt.edu DOI: 10.5195/ahea.2014.142

excellent addition to Barlay's book could be a map showing the reaches of the Austria-Hungarian Empire and the changing borders of Hungary after World Wars I and II, for readers to be better able to place Barlay's scattered ancestors. A map of Budapest locales would likewise be welcome to mark sites of significance and remembrance for Barlay's family, just like in Charles Farkas's book.

The author of this review, an American of non-Hungarian background, stood in 1966 in front of the pocked-marked Hungarian Radio Building and asked herself why the period of Hungarian history from World War II to the Hungarian Revolution was so unknown in the free world. That moment sparked in me a life-long venture into Hungarian topics. I knew that Hungary was the last nation occupied by the Nazis and that after the war ended, the West concentrated on political difficulties, displaced persons, rejoining families, and reconstruction of destroyed cities and countries. The Iron Curtain and the advent of the Cold War prevented much information on Hungary and the other Soviet-ruled nations from reaching the West and America. I decided then and there, outside the Hungarian Radio building, that I would investigate various Hungarian themes and incorporate them into my future research agenda. Books such as Charles Farkas's Vanished by the Danube and Nick Barlay's Scattered Ghosts illuminate actions and reactions to major events in Hungary's twentieth-century history, thus inviting comparisons with other accounts to enable us a broader and more diverse view (on this see Adam Z. Levy's masterful review of the Farkas volume in the Los Angeles Review of Books (January 2, 2014), which also evokes thoughts of Sándor Márai's Memoir of Hungary 1944-1948 (1996); and Zsuzsanna Tóth's review of the Barlay book in Olvassbele (July 20, 2014).

The opportunity to examine multi-generational family memoirs about magnanimous periods can likewise be found in Hungarian-American journalist Charles Fenyvesi's book entitled When the World Was Whole: Three Centuries of Memories (Fenyvesi 1990), in Tamás Kornfeld's Nem mindennapi élet [Not an Everyday Life] (Kornfeld 2014), and in Hungarian-Canadian historian Elaine Kalman Naves' Journey to Vaja: Reconstructing the World of a Hungarian-Jewish Family (Naves 1996). János Bak's engaging article (2012) on twelve of his classmates at Berzenyi Dániel gimnázium in the fifth district of Budapest, with a discussion of one or two generations of the subjects, effectively portrays Jewish life and families of the mid twentieth century. The Book of Fathers, by Miklós Vámos (2009), a popular novel entitled Apák könyve in Hungary and translated into more than a dozen languages, covers twelve generations of men in the Csillag family over a period of 300 years. Ervin Varga offers a retrospective view of Hungary in Living and Dying in Hungary: A Jewish Psychiatrist Looks Back (2012). The autobiographical account One Must Also Be Hungarian (2006) by Ádám Biro, a relative of Barlay on his mother's side, is a reverie of his grandparents, extended family, and their vanished worlds. The Farkas memoir, the Barlay family history and these other multigenerational works all tell of significant events for Hungarians past and present to the future generations in their own family as well as to others interested in Hungarian history and lives.

\section{Works Cited:}

Applebaum, Anne. 2012. Iron Curtain. New York: Doubleday.

Bak, János M. 2012. "Twelve Jewish Boys from the Class of '47 of a Budapest Grammar

School and Their Families: Memories and Reminiscences," East European

Jewish Affairs, 42.3: 243-323.

Barlay, Nick. 2014. Szellemek nyomában - családregény. Budapest: K.U.K. Kiadó. 
Biro, Ruth G. "Review Article: The Vanished Ghosts in Two Hungarian Family Memoirs. Farkas, Charles. 2013. Vanished by the Danube and Barlay, Nick. 2013. Scattered Ghosts." Hungarian Cultural Studies. e-Journal of the American Hungarian Educators Association, Volume 7 (2014): http://ahea.pitt.edu DOI: 10.5195/ahea.2014.142

Barlay, Stephen. 2006. Menekülés és Megérkezés [Escape and Arrival] (trans. Anikó Kocsis, with a foreword by Imre Kertész). Budapest: K.U K. Kiadó.

Barlay, Stephen \& Peter Sasdy. 1957. Four Black Cars (trans. Paul Tabori). London: Putnam. Biro, Ádám. 2006. One Must Also Be Hungarian. Chicago: U of Chicago P.

Davidowitz, Lucy S. 1975. The War against the Jews, 1933-1945. New York: Holt, Rinehart, and Winston.

Deak, Istvan. 2003. Essays on Hitler's Europe. Lincoln: University of Nebraska Press.

Fenyvesi, Charles. 1990. When the World Was Whole: Three Centuries of Memories. New York: Viking.

Judt, Tony. 2005. Postwar: A History of Europe since 1945. New York: Penguin.

Levy, Ádám Z. 2014. "Ghosts at Home," Los Angeles Review of Books, January 2, 2014. lareviewofbooks-org/review/ghosts-home

Kornfeld, Tamás. 2014. Nem mindennapi élet [Not an Everyday Life]. Budapest: Corvina Kiadó, 2014.

Márai, Sándor. 1996. Memoir of Hungary 1944-1948 (trans. Albert Teszla). Budapest: Corvina.

Naves, Elaine Kalman. 1996. Journey to Vaja: Reconstructing the World of a Hungarian-Jewish Family. Montreal: McGill-Queens UP

Tóth, Zsuzsanna. 2014. "Múltunk árnyai," [Shadows of Our Past], Nick Barlay: Szellemeknyomában, http://olvassbele.com/2014/07/20/ múltunk-árnyai-nickbarlay-szellemeknyomai

Ungváry Krisztián. 2001. Budapest Ostroma. Budapest: Corvina.

Vámos, Miklós. 2009. The Book of Fathers (trans. Peter Sherwood). New York: Other Press.

Varga, Ervin. 2012. Living and Dying in Hungary: Jewish Psychiatrist Looks Back. Bloomington, IN: Xlibris. 